\title{
Which is Worse; Divorce or Conflict? Parental Divorce, Interparental Conflict, and its Impact on Romantic Relationship Quality of Young Dating Adults in the Maldives
}

\author{
Aishath Shanoora, Hanina H. Hamsan, Haslinda Abdullah \& Azlina Mohd. \\ Khir
}

To Link this Article: http://dx.doi.org/10.6007/IJARBSS/v10-i15/8253

DOI:10.6007/IJARBSS/v10-i15/8253

Received: 07 September 2020, Revised: 10 October 2020, Accepted: 14 November 2020

Published Online: 30 November 2020

In-Text Citation: (Shanoora et al., 2020)

To Cite this Article: Shanoora, A., Hamsan, H. H., Abdullah, H., \& Khir, A. M. (2020). Which is Worse; Divorce or Conflict? Parental Divorce, Interparental Conflict, and its Impact on Romantic Relationship Quality of Young Dating Adults in the Maldives. International Journal of Academic Research in Business and Social Sciences, 10(15), 325-339.

\section{Copyright: (c) 2020 The Author(s)}

Published by Human Resource Management Academic Research Society (www.hrmars.com) This article is published under the Creative Commons Attribution (CC BY 4.0) license. Anyone may reproduce, distribute, translate and create derivative works of this article (for both commercial and non-commercial purposes), subject to full attribution to the original publication and authors. The full terms of this license may be seen at: http://creativecommons.org/licences/by/4.0/legalcode

Special Issue: Youth and Community Wellbeing: Issues, Challenges and Opportunities for Empowerment V1, 2020, Pg. 325 - 339 http://hrmars.com/index.php/pages/detail/IJARBSS JOURNAL HOMEPAGE

Full Terms \& Conditions of access and use can be found at http://hrmars.com/index.php/pages/detail/publication-ethics 


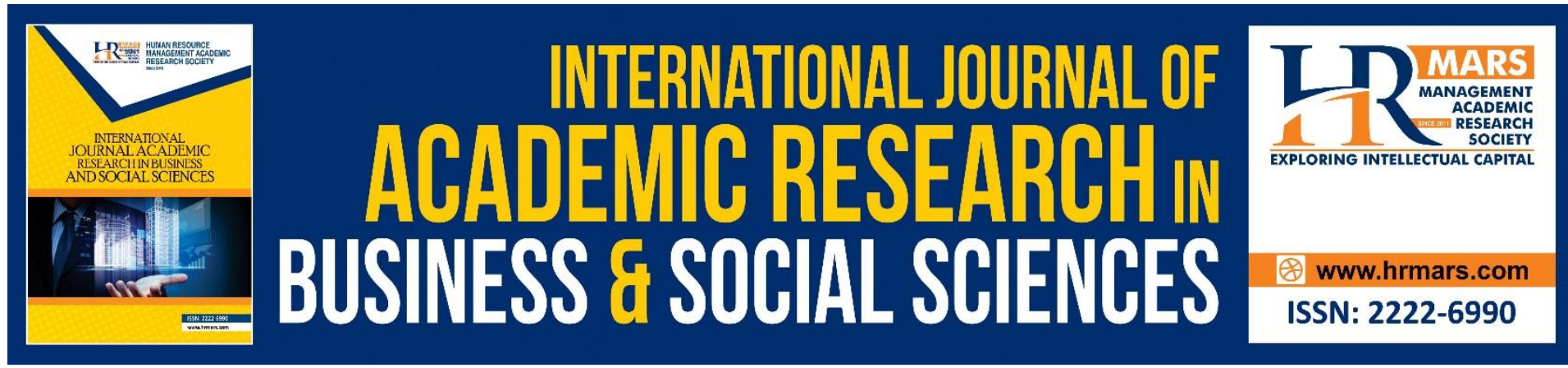

\title{
Which is Worse; Divorce or Conflict? Parental Divorce, Interparental Conflict, and its Impact on Romantic Relationship Quality of Young Dating Adults in the Maldives
}

\author{
Aishath Shanoora², Hanina H. Hamsan ${ }^{1,2}$, Haslinda Abdullah ${ }^{1,2}$ \\ \& Azlina Mohd. Khir ${ }^{2}$ \\ ${ }^{1}$ Institute for Social Science Studies, Universiti Putra Malaysia, 43400 UPM Serdang, \\ Selangor Darul Ehsan, Malaysia, ${ }^{2}$ Faculty of Human Ecology Manusia, Universiti Putra \\ Malaysia, 43400 UPM Serdang, Selangor Darul Ehsan, Malaysia \\ Email: aishath.shanoora@gmail.com, hanina@upm.edu.my, lynn@upm.edu.my,
} m_azlina@upm.edu.my

\begin{abstract}
Past research has documented the negative impact of parental divorce and interparental conflict on romantic relationship quality but in isolated studies. Limited studies have compared both parental divorce and interparental conflict on young adult's dating relationships. This study aimed to fill this gap by identifying the roles of parental divorce and interparental conflict and how they interact on the relationship between parental divorce, interparental conflict, and romantic relationship quality of young adults. A total of 297 Maldivian undergraduate students, who were in a dating romantic relationship, between the ages of 18 to 25 participated in the study. Data was collected using a self-administered set of questionnaires. Relationship quality was measured using the Relationship Quality Component Inventory and perceived interparental conflict was measured using Children's Perception of Interparental Conflict Scale (CPIC). The collected data were analyzed using IBM Statistical Package for Social Sciences (SPSS) and PLS-SEM software. Results revealed that parental divorce and interparental conflict was negatively associated with low romantic relationship quality. Additionally, Perceived interparental conflict mediated the relationship between parental divorce and relationship quality of young dating adults.
\end{abstract}

Keywords: Parental Divorce, Young-Adults, Interparental Conflict, Romantic Relationship Quality, PLS-SEM

\section{Introduction}

A healthy romantic relationship is an indicator of the overall wellbeing of an individual (Adamczyk, 2017). Whereas unhealthy relationships have been associated with psychological and emotional distress (Slotter, Gardner, \& Finkel, 2010). Exploring the development of romantic relationships in young adults are of importance as the development and dissolution 
of a romantic relationship has important implications for their emotional and physical wellbeing (Sbarra, 2006). Additionally, it could also help predict their marriage relationship in the future (Meier \& Allen, 2009), this is especially important in the context of Maldives as a lot of marriages end in divorce every year. Hence, it is important to identify the factors that contribute to the development of building healthy romantic relationships. Family factors have often been recognized as relevant and important in this regard (Conger, Cui, Bryant, \& Elder, 2000). Short- and long-term impact of family structure and family characteristics on children has been often explored by researchers (Andreas \& Kurt, 2013; Gager, Yabiku, \& Linver, 2016; Lucas-Thompson \& George, 2017), however, most literature has explored the effect of parental divorce on children's outcomes at different stages of development (Amato \& DeBoer, 2001; Sun, 2001). One of the most established findings in this area is that compared to children from intact families children who have experienced divorce are more prone to dissolve their relationships as a result of lack of commitment (Amato, 1996). Nevertheless, the role of family characteristics such as interparental conflict and the long-term effect it has on young adults have been sparsely explored. The limited studies exploring interparental conflict has mainly focused on married couples and less importance have been given to young adults in dating relationships even when it has been established that romantic relationships in young adults are of importance (Collins \& van Dulmen, 2006). This study addresses this issue by investigating the role of parental divorce and interparental conflict on young dating adult's romantic relationship quality.

\section{Parental Divorce and Interparental Conflict in the Maldives}

The impact of parental divorce on children and young adults has been widely studied around the globe (see Amato, 1996; Cohen, Orna, Finzi-Dottan, \& Ricky, 2005; Lee, 2018; Morrison, Fife, \& Hertlein, 2017). The Maldives is one of the countries with the highest number of divorces. The rate of divorce in the Maldives has been on the rise for the past decade (Statistical Pocketbook-2017, 2017). In 2002, Maldives made its way into the genius book of world records as the country with the highest number of divorces ("Highest divorce rate ", 2002). Past research has suggested that interparental conflict is involved during the process of divorce, especially during the pre-divorce period (Gager et al., 2016; Wallerstein \& Lewis, 2004). In a country with such a high number of divorces, it is safe to assume that most if not all parents who go through the process of divorce would have had some amount of conflict. However, there is no published research exploring the impact of interparental conflict on young adults dating romantic relationships in the Maldives. This study aims to fill this gap by exploring the interaction of parental divorce and interparental conflict on the quality of young dating adults' romantic relationships in the Maldives.

\section{Social Learning Theory}

Social learning theory is useful in understanding how family factors such as interparental conflict and parental divorce may influence the romantic relationship quality of young dating adults. According to social learning theory, behaviors are learned through observing the actions of others (Bandura, 1977). The emphasis of social learning theory lays around the idea that individuals are likely to adopt behaviors of model figures if the result of the outcome is of value to them (Kapinus, 2005). Through observation of their parent's (model figures) marital interactions, young adults may shape their romantic relationships. When children observe the process of parental divorce and conflict behaviors of parents, they may learn and apply these behaviors in their adult romantic relationships which may influence the quality of 
the romantic relationship. Hence, social learning theory can be considered a useful ground to understand the influence of interparental conflict and parental divorce on young dating adult's romantic relationship quality.

\section{The Effects of Parental divorce on Young Dating Adult's Romantic Relationship Quality}

Throughout our life, we make a lot of decisions, as such, during young adulthood decisions regarding career, and romantic relationships are made (Jackson \& Fife, 2018). Young adulthood is the stage of development, where people deal with the psychosocial crisis of intimacy vs. isolation (Erikson, 1963). This is the stage where individuals begin to explore relationships leading towards long term commitment with someone else other than a family member. Successful completion of the stage results in a sense of commitment and happier and healthier relationships, however, fearing to commit to a relationship and avoiding intimacy can lead to loneliness and isolation. Questions about how parental divorce could influence the experiences and decisions made by young adults during this stage have been sparsely explored in past research.

Even though many past studies have explored the long-term effect of parental divorce on children and adolescents (see Amato, 1993; Clarke-Stewart, Vandell, McCartney, Owen, \& Booth, 2000; Wallerstein, Lewis, \& Packer Rosenthal, 2013), fewer studies have focused on young adults and how parental divorce impact their adult relationships. Among the small number of studies exploring the impact of parental divorce and romantic relationships, few have identified potential outcomes for adult children of divorce. For example, Mustonen, Huurre, Kiviruusu, Haukkala, and Aro (2011) in their research found that compared to young adults from intact families, young adults from divorced families had more difficulty to form and maintain close relationships. They also identified a poor intimate quality among girls from divorced parents. Similarly, Wallerstein and Lewis (2004) also found that children from divorced families had difficulties in achieving love, intimacy, and commitment to marriage.

Adding on, parental divorce also influences how people perceive their romantic relationship. Children who experience parental divorce shows less commitment in their relationship and views divorce as an easy solution for the challenges they face in the relationship (Braithwaite, Doxey, Dowdle, \& Fincham, 2016; Cui, Fincham, \& Durtschi, 2011). Trust is another factor that contributes to the quality of a relationship, past research has also revealed that children from divorced families have lower levels of trust towards their romantic partners (Duran-Aydintug, 1997; Shulman, Scharf, Lumer, \& Maurer, 2001). Furthermore, experiencing parental divorce impacts the level of romantic relationship satisfaction in young adults (Roper, Fife, \& Seedall, 2020). In a gender comparison of young adults from divorced and intact families, Jacquet and Surra (2001), found that women from divorced families were less satisfied in their romantic relationship. Similar findings were reported by Sassler, Cunningham, and Lichter (2009), who concluded that compared to young adults from intact families, young adults from divorced families were less satisfied in their romantic relationships and had heightened perceptions of their romantic relationship would end.

Although previous research has investigated the impact of parental divorce on the quality of romantic relationships in young adults, most of the research has focused on one or two components of relationship quality such as commitment, trust, and satisfaction in isolation. In this study, we have tried to fill this gap by measuring the overall quality of romantic 
relationships including the domains of romantic relationship quality suggested by Fletcher and Simpson (2000). Specifically, we included commitment, love, satisfaction, intimacy, passion, and trust to understand the overall quality of the romantic relationship of young adults as all these domains play an important role in the quality of the romantic relationship.

\section{Effect of Interparental Conflict on Young Dating Adult's Romantic Relationship Quality}

The perceived interparental conflict has often been associated with the romantic relationship quality of young adults in past research (Cui, Fincham, \& Pasley, 2008; Segrin, Taylor, \& Altman, 2005). Conflict is frequently caused by a difference in perspectives, desires, values, interests, or goals and is unavoidable in any adult relationship (Baron \& Branscombe, 2012). Often, parental divorce is accompanied by conflict. Children's perception of interparental conflict could vary depending on the intensity, frequency, and content of the conflict (Grych, Raynor, \& Fosco, 2004). Past research has associated interparental conflict with romantic relationship conflict (Simon \& Furman, 2010). Kwan, Mellor, Rizzuto, Kolar, and Bt. Mamat (2013), found that interparental conflict; specifically, the frequency and intensity of conflict was associated with romantic relationship quality. Similar findings were reported by Cui and Fincham (2010), these authors propose that the severity of perceived conflict before the parental divorce has an impact on the children's perception of the quality of their parents' divorce, and this variation in perception has been associated with relationship commitment.

Past studies have suggested the likelihood of an interactive effect between interparental conflict and parental divorce. For example, Amato and DeBoer (2001) explored the interactive effect of parental conflict and divorce in romantic relationship outcomes of young adults and concluded that if parents reported low levels of conflict rather than high levels before marital dissolution, divorce was more likely to be transmitted across generations. Additionally, Cui et al. (2011), suggests that when high levels of conflict are observed before the parental divorce, children are in favor of their parents' divorce, forming a positive attitude towards divorce which impacts their future romantic relationship. Furthermore, in the absence of parental divorce, parental conflict is associated with less relationship satisfaction and stability in young adults' romantic relationships (Braithwaite et al., 2016). Most of the literature in this area has focused on exploring the interaction of these variables in Western countries, However, Maldives is an Asian country with a record of an extremely high number of divorces every year. Hence, exploring the interaction of these variables among Maldivian young adults will contribute to the existing literature, in understanding a different population.

\section{The Current Study}

The present study aimed to investigate the interaction between parental divorce and perceived interparental conflict and romantic relationship quality of young dating adults. Informed by social learning theory and based on the reviewed literature, we hypothesized that:

H1. Parental divorce will have a direct negative relationship with the romantic relationship quality of young dating adults.

It was hypothesized that individuals who experience parental divorce will have a lower quality of the romantic relationship, as past research has shown that experiencing parental divorce leaves a child with long term negative effects, especially on their close relationships. 
H2. Perceived interparental conflict will have a direct negative relationship with the romantic relationship quality of young dating adults.

It was hypothesized that interparental conflict will have a negative relationship with romantic relationship quality. Social learning theory suggests that children learn through observation and imitation of their role models, so it is assumed that children who are exposed to severe parental conflicts will have learned conflicting behaviors they may bring to the existing romantic relationship resulting in a reduction of the overall quality of the relationship.

H3. Perceived interparental conflict will mediate the relationship between parental divorce and romantic relationship quality.

It was hypothesized that interparental conflict will mediate the relationship between parental divorce and young dating adult's relationship quality. Limited research has suggested that it is not the divorce by itself that impacts young adults' romantic relationships, but it is how children perceive the conflict involved in the process of the divorce.

\section{Method}

\section{Participants}

Participants of the study were university/college students from the Maldives. Of 488 students in the original sample, 297 students between the ages of 18 to 25 who identified themselves as being in a dating romantic relationship were recruited for this study. The total participants consisted of 223 (75.1\%) females and 74 (24.9\%) males, with a mean age of 20.88 years. At the time of data collection, all participants were in committed dating romantic relationships.

\section{Procedure}

Data was collected using a self-administering questionnaire, Participants for the study were identified by asking an oral question "are you currently in a romantic relationship?" All participants who answered the question as 'yes' were recruited for the study. At this point we did not identify or differentiate participants who were dating or who were married, this question was included in the questionnaire. The differentiation was made during the analysis of the study. All participants were given information about the study and signed consent was taken. Next, they were asked to fill in a set of questionnaires including demographic questions about themselves, their parents, perceived relationship quality component scale, and perceived interparental conflict scale. All demographic data were analyzed using IBM Statistical Package for Social Sciences (SPSS). SmartPLS 3.0 software was used to analyze the structural equation modeling of partial least squares. (Hair, Sarstedt, Hopkins, \& Kuppelwieser, 2014)

\section{Measures}

Romantic relationship quality: Six components (love, commitment, trust, satisfaction, passion, and intimacy) of relationship quality were measured using the perceived relationship quality component inventory (Fletcher, Simpson, \& Thomas, 2000). It is an 18 items Likert scale ranging from 1 (not at all) to 7 (extremely) measuring the 6 different components of romantic relationship qualities. All items of the scale were averaged to get a total score for 
relationship quality. Higher scores reflected better relationship quality and lower scores reflected lower relationship quality. The alpha coefficient for this scale was .88 .

Perceived Interparental conflict was measured using the Children's Perception of Interparental Conflict Scale (CPIC) developed by Grych, Seid, and Fincham (1992). The scale consisted of 48 items organized into nine subscales: Frequency ("I often saw or heard my parents arguing"), Intensity, ("my parents got really mad when they argued"), Resolution, ("When my parents argue, they don't makeup away"), Content, ("My parent's arguments were usually about me"), Threat, ("I get scared when my parents argue"), Coping Efficacy, ("I don't know what to do when my parents argue"), Self-Blame, ("I was to blame when my parents had arguments"), Triangulation, ("my mom want me to be on her side when she and my dad argue"), and Stability, ("the reasons my parents argued never changed"). Participants rated each item on a six-point Likert scale, ranging from 1 (completely false) to 6 (completely true). Items were recoded when necessary, and all items from all subscale were averaged so that higher scores indicate higher perception of interparental conflict. The alpha coefficient for the scale was .71

Demographics. Information about participant's age, gender, relationship status, and parents' marital status were gathered. Responses for parental marital status were coded as $0=$ married and $1=$ divorced for analysis.

\section{Results}

\section{Descriptive Statistics}

Out of the 297 participants, 226 participants had experienced parental divorce. The mean age at which participants had experienced parental divorce was 10.38 (SD =5,74). The mean duration of the relationship of participants was 26.01months. Most of the participants (84.8\%) from divorced families reported a low-quality relationship and high levels of perceived interparental conflict (94.5\%). The majority of the participants from intact families also reported low levels of relationship quality (64.4\%) and high levels of interparental conflict (88.0\%).

\section{Measurement Model}

Before analyzing the structural model, the measurement model was analyzed. Table 1 depicts the construct reliability and convergent validity for all the variables in this study. The model demonstrates high levels of internal consistency of the items with a composite reliability level of 0.957 (RQ) and 0.951 (PIC). 
Table 1: Internal consistency and convergent validity

\begin{tabular}{llrrc}
\hline Construct & Items & Loading & CR & AVE \\
\hline Relationship Quality (RQ) & Commitment & 0.902 & 0.957 & 0.790 \\
& Intimacy & 0.922 & & \\
& Love & 0.908 & & \\
& Passion & 0.824 & & \\
& Satisfaction & 0.949 & & \\
& Trust & 0.820 & & \\
Perceived interparental conflict & Content & 0.807 & 0.951 & 0.683 \\
(PIC) & & & & \\
& Coping & 0.909 & & \\
& Frequency & 0.864 & & \\
& Intensity & 0.914 & & \\
& Perceived- & 0.791 & & \\
& Threat & & & \\
& Resolution & 0.785 & & \\
& Self-Blame & 0.712 & & \\
& Stability & 0.754 & & \\
\hline
\end{tabular}

The minimum threshold value of 0.5 for variance extracted (AVE) was achieved by all constructs demonstrating that more than $50 \%$ of the variance in the construct is explained by the items (Hair, Hult, Ringle, \& Sarstedt, 2014). Discriminant validity was established using Fornell and Larcker (1981) criterion and HTMT criterion (Henseler, Ringle, \& Sarstedt, 2015), the results are displayed in tables 2 and 3 . 
Table 2. Fornell and Larcker criterion

\begin{tabular}{llll}
\hline & PIC & PD & RQ \\
\hline PIC & 0.827 & & \\
PD & 0.244 & 1.000 & \\
RQ & -0.796 & -0.341 & 0.889 \\
\hline
\end{tabular}

Notes: Diagonal elements represent the square root of AVE. Off diagonal elements are simple bivariate correlations between the constructs

Table 3. HTMT criterion

\begin{tabular}{llll}
\hline & PIC & PD & RQ \\
\hline PIC & & & \\
PD & 0.249 & & \\
RQ & 0.838 & 0.350 & \\
\hline
\end{tabular}

Note. Criteria: discriminant validity is established at $\mathrm{HTMT}_{0.85 \text {, }}$

Fornell and Larcker (1981) criterion confirmed that the AVE square roots were larger than the correlations among constructs, indicating that all constructs are different from each other. Besides, all values of the constructs passed the threshold value of $\mathrm{HTMT}_{0.85}$ (Kline, 2016) and $\mathrm{HTMT}_{0.90}$ (Gold, Malhotra, \& Segars, 2001) demonstrating that discriminant validity was established for the measurement model.

\section{Structural model - Hypothesis testing}

Next, the structural model was tested for collinearity issues using the variance inflated factor (VIF). All constructs were lower than the threshold value of 3.3 (Diamantopoulos \& Siguaw, 2006), indicating that there were no colinearity issues among the constructs. Table 4 illustrates the direct relationships of the variables.

Table 4. Direct relationships

\begin{tabular}{llccccc}
\hline Hypothesis & Relationship & $\begin{array}{c}\text { Direct } \\
\text { effect (B) }\end{array}$ & $\begin{array}{c}\text { Std.Erro } \\
\mathrm{r}(\mathrm{SE})\end{array}$ & $\begin{array}{c}\mathrm{T}- \\
\text { Statistic } \\
\mathrm{s}\end{array}$ & $\begin{array}{c}\mathrm{P} \\
\text { Values }\end{array}$ & $\begin{array}{c}\text { Relationshi } \\
\mathrm{p} \\
\text { Established }\end{array}$ \\
\hline $\mathrm{H} 1$ & $\mathrm{PIC} \rightarrow \mathrm{RQ}$ & -0.758 & 0.038 & 19.968 & 0.000 & Yes \\
$\mathrm{H} 2$ & $\mathrm{PD} \rightarrow \mathrm{RQ}$ & -0.156 & 0.045 & 3.471 & 0.000 & Yes \\
\hline \multicolumn{7}{c}{ Notes. one-tailed }
\end{tabular}

According to table 4 perceived interparental conflict had a negative direct relationship with romantic relationship quality, $(P I C \rightarrow R Q, \beta=-0.758, t=19.968)$. Additionally, Parental divorce was negatively associated with relationship quality $(P D \rightarrow R Q, \beta=-0.156, t=3.471)$. 
Table 5. Indirect relationships

\begin{tabular}{|c|c|c|c|c|c|c|c|c|}
\hline & \multirow{2}{*}{ Relationship } & \multirow{2}{*}{$\begin{array}{l}\text { Indirec } \\
\text { t effect } \\
\text { (ß) }\end{array}$} & \multirow{2}{*}{$\begin{array}{l}\text { Std.Error } \\
\text { (SE) }\end{array}$} & \multirow{2}{*}{$\begin{array}{l}\text { t- } \\
\text { value }\end{array}$} & \multirow{2}{*}{$\begin{array}{l}p- \\
\text { value }\end{array}$} & \multirow{2}{*}{ Decision } & 2.5 & 97.5 \\
\hline & & & & & & & $\mathrm{LL}$ & UL \\
\hline H3 & $\mathrm{PD} \rightarrow \mathrm{PIC} \rightarrow \mathrm{RQ}$ & -0.185 & 0.047 & 3.923 & 0.000 & $\begin{array}{c}\text { supporte } \\
\text { d }\end{array}$ & -0.277 & -0.096 \\
\hline
\end{tabular}

Notes. two-tailed

The results for the hypothesized indirect relationship is shown in table 5 . The hypothesized indirect relationship was found significant at a 99 percent confidence interval $(P D \rightarrow P I C \rightarrow R Q$, $\beta=-0.185, t=3.923)$. The bootstrap confidence interval values for the hypothesis did not straddle a zero between the lower and the upper intervals. Therefore, it was concluded Perceived interparental conflict mediated the relationship between parental divorce and romantic relationship quality of young dating adults.

Table 6. Determination of coefficient $\left(\mathrm{R}^{2}\right)$, effect size $\left(f^{2}\right)$, and predictive relevance $\left(\mathrm{Q}^{2}\right)$

\begin{tabular}{lcccc}
\hline & $\begin{array}{c}\text { Co-efficient of } \\
\text { determination }\end{array}$ & Predictive relevance & & Effect size $\left(f^{2}\right)$ \\
\hline$R^{2}$ & $Q^{2}$ & $R Q$ & Effect Size \\
RQ & 0.654 & 0.507 & & \\
PIC & & & 1.571 & Large \\
PD & & & 0.057 & Small \\
\hline
\end{tabular}

Finally, Table 6 shows the results for the coefficient of determination $\left(R^{2}\right)$, the effect size $\left(f^{2}\right)$, and the predictive relevance $\left(Q^{2}\right)$ of exogenous variables on the endogenous variable. The results showed that $R^{2}$ was 0.654 , suggesting that the exogenous variables in the study, which were parental divorce and perceived interparental conflict explain 65.4 percent of the variance in relationship quality of young adults. The $Q^{2}$ value 0.507 for $R Q$ was larger than 0 (Hair, Sarstedt, et al., 2014) suggesting that all exogenous values in the model hold predictive ability over the endogenous variable. While perceived interparental conflict (PIC, $f=1.571$ ) had a large effect size on relationship quality, parental divorce (PD, $f=0.057$ ) was found to have a small effect size on relationship quality.

\section{Discussion}

The current study is the first study examining the interaction effect of parental divorce and perceived interparental conflict of young Maldivian dating adult's romantic relationship quality. Drawn from existing literature and social learning theory it was hypothesized that both interparental conflict and parental divorce will have a relationship with young dating adult's romantic relationship quality.

Consistent with prior studies, our analysis showed that coming from a divorced family decreased the level of romantic relationship quality of young adults in dating relationships. Previous studies have shown that young adults who have experienced parental divorce have low levels of commitment in their relationship (Amato, 1996; Braithwaite et al., 2016; Cui et al., 2011; Wallerstein \& Lewis, 2004), low level of trust towards their romantic partners (Shulman et al., 2001), and low satisfaction within the relationship (Amato \& DeBoer, 2001; Roper et al., 2020). An explanation of the relationship between parental divorce and romantic 
relationship quality can be derived from social learning theory which suggests, children learn interpersonal behaviors and relationship skills and attitudes through observing parental models. According to this perspective, children who experience parental divorce and marital dissatisfaction have little opportunity to learn the necessary interpersonal skills that facilitate the making and maintenance of longterm relationships affecting the quality of the relationship. Parental divorce is lifelong acute stress that is life-transforming to the child and what they learn in their childhood is carried into their adult relationships. When children of divorce reach the stage of adulthood, they lack proper model images of how two partners make and maintain a stable relationship, and this becomes a barrier that blocks the journey of those children's development (Wallerstein \& Lewis, 2004). Good internal images of parents as a couple is important for the growing child to make their future relationships successful, these images, they create during childhood increases the chance of surviving confronting situations they face in their relationship.

A strong negative relationship between perceived interparental conflict and romantic relationship quality of young adults in dating relationships was also found in this study. These results support past studies that have suggested perceived interparental conflict affects the quality of romantic relationships (Cui \& Fincham, 2010; Simon \& Furman, 2010). In the process of divorce, if higher levels of interparental conflict are involved, the effect it has on the offspring's romantic relationship quality is different compared to divorces with less or no conflict children exposed to high levels of interparental conflict may develop similar expectations for their romantic partners, meaning that they may also choose to deal with the problems they face in the relationship using conflict as that is what they have learned from their parents. Even though we did not aim at finding out how interparental conflict impacted the romantic relationship quality of young adults from intact families, we found that high levels of interparental conflict was observed and recorded by children from intact families. Past research has also suggested that interparental conflict increases instability in offsprings relationship even in the absence of parental divorce (Braithwaite et al., 2016). Many participants from intact families in this study have reported observing high levels of interparental conflict, hence, the results of this study should be interpreted with caution.

Our third hypothesis was, perceived interparental conflict will mediate the relationship between parental divorce and young dating adult's quality of romantic relationships. This hypothesis was also excepted and thus, we concluded that interparental conflict was one mechanism by which parental divorce influence young adult's romantic relationships. These findings are partly consistent with previous research where they have established a relationship with parental divorce and romantic relationship quality (Lee, 2018) and interparental conflict and romantic relationship (Li \& Yang, 2019). This study adds to the existing literature by finding a mediation effect of interparental conflict on the relationship with parental divorce and romantic relationship quality. Hence, it can be suggested that the amount of conflict observed by the children and how they perceive the conflict determines the impact it has on their romantic relationship.

The effect size of parental divorce and interparental conflict on the quality of romantic relationships suggest that interparental conflict has a larger effect size on romantic relationship quality compared to parental divorce. This suggests that, even though parental divorce has a negative effect on adult children's relationship quality, interparental conflict is 
worse for young adult's romantic relationships. Past research has also suggested that if there is a lot of conflict between parents, many children get a sense of relief when their parents divorce. This is an area that needs to be further explored for the Maldivian population in future research.

\section{Limitations and Implications}

It is important to note the limitation of this study when interpreting the results. First, the measures used in this study were retrospective self-reports, and both interparental conflict and romantic relationship quality were reported by the participants. This could have an inflated association among the constructs. However, it is also possible that young adults' reports of their perceptions of parental conflict are more accurate, as their perceptions may be more relevant to their representation of their current relationship than either the parent or the researcher. And for this study on how participants perceived interparental conflict, and its effect on their current relationship, their perception is more meaningful. Second, the subsample of participants from married families was very small $(\mathrm{N}=71)$ for testing the current model. Third, the sample had a vast imbalance in gender, thus future studies should incorporate larger samples consisting of a greater representation of the general population.

\section{Conclusions}

Despite the limitations, this study builds on and extended the previous research concerning parental divorce, interparental conflict, and dating adults' romantic relationship quality. The findings suggest that parental divorce and interparental conflict was associated with low quality of the romantic relationship. It also revealed that interparental conflict mediates the relationship between parental divorce and romantic relationship quality. Furthermore, the effect size of interparental conflict on romantic relationship quality is more compared to parental divorce. The findings of this research will be valuable to therapists as it can be used to identify potential interventions to reduce the adverse effect of interparental conflict and parental divorce on young adult's romantic relationships.

\section{References}

Adamczyk, K. (2017). Voluntary and Involuntary Singlehood and Young Adults' Mental Health: an Investigation of Mediating Role of Romantic Loneliness. Current Psychology, 36(4), 888-904.

Amato, P. R. (1993). Children's Adjustment to Divorce: Theories, Hypotheses, and Empirical Support. Journal of Marriage and Family, 55(1), 23-38.

Amato, P. R. (1996). Explaining the Intergenerational Transmission of Divorce. Journal of Marriage and the Family, 58(3), 628.

Amato, P. R., \& DeBoer, D. D. (2001). The Transmission of Marital Instability across Generations: Relationship Skills or Commitment to Marriage? Journal of Marriage and Family, 63(4), 1038-1051.

Andreas, D., \& Kurt, S. (2013). The Intergenerational Transmission of Divorce: A FifteenCountry Study with the Fertility and Family Survey. Comparative Sociology, 12(2), 211235.

Bandura, A. (1977). Social learning theory. Englewood Cliffs, N.J.: Englewood Cliffs, N.J. : Prentice Hall.

Baron, R. A., \& Branscombe, N. R. (2012). Social Psychology (13 ed.): Pearson. 
Braithwaite, S. R., Doxey, R. A., Dowdle, K. K., \& Fincham, F. D. (2016). The Unique Influences of Parental Divorce and Parental Conflict on Emerging Adults in Romantic Relationships. Journal of Adult Development, 23(4), 214-225.

Clarke-Stewart, A., Vandell, D. L., McCartney, K., Owen, M. T., \& Booth, C. (2000). Effects of Parental Separation and Divorce on Very Young Children. Journal of Family Psychology, 14(2), 304-326.

Cohen, L., Orna, Finzi-Dottan, \& Ricky. (2005). Parent-child relationships during the divorce process; from attachment theory and intergenerational perspective. Contemporary Family Therapy, 27(1), 81-99.

Collins, A., \& van Dulmen, M. (2006). Friendships and Romance in Emerging Adulthood: Assessing Distinctiveness in Close Relationships: American Psychological Association.

Conger, R. D., Cui, M., Bryant, C. M., \& Elder, G. H. (2000). Competence in Early Adult Romantic Relationships: A Developmental Perspective on Family Influences. Journal of Personality and Social Psychology, 79(2), 224-237.

Cui, M., \& Fincham, F. D. (2010). The differential effects of parental divorce and marital conflict on young adult romantic relationships. Personal Relationships, 17(3), 331-343.

Cui, M., Fincham, F. D., \& Durtschi, J. A. (2011). The effect of parental divorce on young adults' romantic relationship dissolution: What makes a difference? Personal Relationships, 18(3), 410-426.

Cui, M., Fincham, F. D., \& Pasley, B. K. (2008). Young Adult Romantic Relationships: The Role of Parents' Marital Problems and Relationship Efficacy. Personality and Social Psychology Bulletin, 34(9), 1226-1235.

Diamantopoulos, A., \& Siguaw, J. A. (2006). Formative Versus Reflective Indicators in Organizational Measure Development: A Comparison and Empirical Illustration. British Journal of Management, 17(4), 263-282.

Duran-Aydintug, C. (1997). Adult Children of Divorce Revisited: When They Speak Up. Journal of Divorce \& Remarriage, 27(1-2), 71-83.

Erikson, E. H. (1963). Childhood and society (2nd Edition ed.). New York: WW Norton.

Fletcher, G. J. O., \& Simpson, J. A. (2000). Ideal Standards in Close Relationships:Their Structure and Functions. Current Directions in Psychological Science, 9(3), 102-105.

Fletcher, G. J. O., Simpson, J. A., \& Thomas, G. (2000). The Measurement of Perceived Relationship Quality Components: A Confirmatory Factor Analytic Approach. Personality and Social Psychology Bulletin, 26(3), 340-354.

Fornell, C., \& Larcker, D. (1981). Evaluating Structural Equation Models with Unobservable Variables and Measurement Error. Journal of Marketing Research, 18(1), 39.

Gager, C. T., Yabiku, S. T., \& Linver, M. R. (2016). Conflict or Divorce? Does Parental Conflict and/or Divorce Increase the Likelihood of Adult Children's Cohabiting and Marital Dissolution? Marriage \& Family Review, 52(3), 243-261.

Gold, A. H., Malhotra, A., \& Segars, A. H. (2001). Knowledge Management: An Organizational Capabilities Perspective. Journal of Management Information Systems, 18(1), 185214.

Grych, J. H., Raynor, S. R., \& Fosco, G. M. (2004). Family processes that shape the impact of interparental conflict on adolescents. Dev Psychopathol, 16(3), 649-665.

Hair, J., Hult, G. T. M., Ringle, C., \& Sarstedt, M. (2014). A Primer on Partial Least Squares Structural Equation Modeling. 
Hair, J., Sarstedt, M., Hopkins, L., \& Kuppelwieser, V. (2014). Partial Least Squares Structural Equation Modeling (PLS-SEM): An Emerging Tool for Business Research. European Business Review, 26, 106-121.

Henseler, J., Ringle, C. M., \& Sarstedt, M. (2015). A new criterion for assessing discriminant validity in variance-based structural equation modeling. Journal of the Academy of Marketing Science, 43(1), 115-135.

Highest divorce rate. (2002). Retrieved from https://www.guinnessworldrecords.com/worldrecords/highest-divorce-

rate\#: :text=According\%20to\%20the\%20UN\%2C\%20the,the\%20United\%20States\%2 Owih\%204.34.

Jackson, L. J., \& Fife, S. T. (2018). The Impact of Parental Divorce: The Relationship Between Social Support and Confidence Levels in Young Adults. Journal of Divorce \& Remarriage, 59(2), 123-140.

Jacquet, S. E., \& Surra, C. A. (2001). Parental Divorce and Premarital Couples: Commitment and Other Relationship Characteristics. Journal of Marriage and Family, 63(3), 627638.

Kapinus, C. A. (2005). The Effect of Parental Marital Quality on Young Adults' Attitudes toward Divorce. Sociological Perspectives, 48(3), 319-335.

Kline, R. B. (2016). Principles and practice of structural equation modeling (Fourth edition. ed.): New York : The Guilford Press.

Kwan, L. L.-Y., Mellor, D., Rizzuto, L., Kolar, C., \& Bt. Mamat, N. H. (2013). The Relationship Between Perceived Interparental Conflict and Malaysian Young Adults' Attitudes Toward Divorce. Journal of Divorce \& Remarriage, 54(7), 596-607.

Lee, S. A. (2018). Parental Divorce, Relationships with Fathers and Mothers, and Children's Romantic Relationships in Young Adulthood. J. Adult Dev., 25(2), 121-134.

Li, D., \& Yang, K. (2019). Interparental conflict and Chinese emerging adults' romantic relationship quality: Indirect pathways through attachment to parents and interpersonal security. Journal of Social and Personal Relationships, 37(2).

Lucas-Thompson, R. G., \& George, M. W. (2017). Are There Individual and Sibling Differences in Appraisals of Interparental Conflict? Journal of Family Psychology, 31(7), 933-938.

Meier, A., \& Allen, G. (2009). Romantic Relationships from Adolescence to Young Adulthood: Evidence from the National Longitudinal Study of Adolescent Health. The Sociological Quarterly, 50(2), 308-335.

Morrison, S. C., Fife, S. T., \& Hertlein, K. M. (2017). Mechanisms behind Prolonged Effects of Parental Divorce: A Phenomenological Study. Journal of Divorce \& Remarriage, 58(1), 44-63.

Mustonen, U., Huurre, T., Kiviruusu, O., Haukkala, A., \& Aro, H. (2011). Long-Term Impact of Parental Divorce on Intimate Relationship Quality in Adulthood and the Mediating Role of Psychosocial Resources. Journal of Family Psychology, 25(4), 615-619.

Roper, S. W., Fife, S. T., \& Seedall, R. B. (2020). The Intergenerational Effects of Parental Divorce on Young Adult Relationships. Journal of Divorce \& Remarriage, 61(4), 249266.

Sassler, S., Cunningham, A., \& Lichter, D. T. (2009). Intergenerational Patterns of Union Formation and Relationship Quality. Journal of Family Issues, 30(6), 757-786.

Sbarra, D. A. (2006). Predicting the Onset of Emotional Recovery Following Nonmarital Relationship Dissolution: Survival Analyses of Sadness and Anger. Personality and Social Psychology Bulletin, 32(3), 298-312. 
Segrin, C., Taylor, M. E., \& Altman, J. (2005). Social cognitive mediators and relational outcomes associated with parental divorce. Journal of Social and Personal Relationships, 22(3), 361-377.

Shulman, S., Scharf, M., Lumer, D., \& Maurer, O. (2001). Parental Divorce and Young Adult Children's Romantic Relationships: Resolution of the Divorce Experience. American Journal of Orthopsychiatry, 71(4), 473-478.

Simon, V. A., \& Furman, W. (2010). Interparental Conflict and Adolescents' Romantic Relationship Conflict. Journal of Research on Adolescence, 20(1), 188-209.

Slotter, E. B., Gardner, W. L., \& Finkel, E. J. (2010). Who Am I Without You? The Influence of Romantic Breakup on the Self-Concept. Personality and Social Psychology Bulletin, 36(2), 147-160.

Statistical Pocketbook-2017. (2017). Retrieved from http://statisticsmaldives.gov.mv/spb2017/

Sun, Y. (2001). Family Environment and Adolescents' Well-Being Before and After Parents' Marital Disruption: A Longitudinal Analysis. Journal of Marriage and Family, 63(3), 697-713.

Wallerstein, J. S., Lewis, J., \& Packer Rosenthal, S. (2013). Mothers and Their Children After Divorce: Report From a 25-Year Longitudinal Study. Psychoanalytic Psychology, 30(2), 167-184.

Wallerstein, J. S., \& Lewis, J. M. (2004). The Unexpected Legacy of Divorce: Report of a 25Year Study. Psychoanalytic Psychology, 21(3), 353-370. 